\title{
SOCIAL WASP FAUNA CHYMENOPERA: POLISTINAE] FROM THE CAATINGA AND THE ATLANTIC FOREST OF THE STATE OF BAHIA, BRAZIL
}

\author{
FAUNA DE VESPAS SOCIAIS CHYMENOPTERA: \\ POLISTINAEJ DA CAATINGA EMATA ATLÂNTICA DOESTADO DA BAHIA, BRASIL
}

Oziel Sanatana Neri Trindade

Lúcio Flávio Freire Lima²

Gisele Garcia Azevedo

Juvenal Cordeiro Silva Junior ${ }^{4}$

\begin{abstract}
In this work, we carried out an inventory of social wasps (Hymenoptera, Polistinae) from remnants of Caatinga and Atlantic Forest from the central-south region of the state of Bahia. Nest sampling was carried out in the period from March 2010 to June 2011, using the method of active search. We obtained 90 nests and identified 22 species, three subspecies and one morphospecies of social wasp belonging to ten genera and eight subgenera. Five species were recorded for the first time in the state of Bahia, and the genus Polybia was the most frequent one, with seven identified species. The obtained results confirmed the diversity of the Atlantic Forest, and point to a rich fauna of social wasps in the Caatinga.
\end{abstract}

Key words: Inventory, Wasp diversity, Social wasp, Vespidae.

\section{Resumo}

Neste trabalho foi realizado um inventário da fauna de vespas sociais (Vespidae: Polistinae) em áreas de transição entre Caatinga e Mata Atlântica da região Centro Sul do Estado da Bahia, Brasil. As amostragens dos ninhos de vespas sociais foram realizadas no período de março de 2010 a junho de 2011 . O método de amostragem foi o de busca ativa dos ninhos. Dos 90 ninhos coletados, foram identificadas 22 espécies, três subespécies e uma morfoespécie de vespas sociais pertencentes a dez gêneros e oito subgêneros. Cinco espécies foram registradas pela primeira vez para o estado da Bahia. O gênero Polybia foi o mais frequente com sete espécies identificadas. Os resultados obtidos nesse trabalho comprovaram a diversidade de espécies descritas para outras fitofisionomias do estado da Bahia.

1 Universidade Estadual do Sudoeste da Bahia, Departamento de Ciências Biológicas, Jequié, BA, Brazil. E-mail: ozzybiologo@yahoo.com.br

2 Universidade Estadual do Sudoeste da Bahia, Departamento de Ciências Biológicas, Jequié, BA, Brazil. E-mail: luciolimaı@@hotmail.com

3 Universidade Estadual do Sudoeste da Bahia, Departamento de Ciências Biológicas, Jequié, BA, Brazil. E-mail: gisabelha@yahoo.com.br

4 Universidade Estadual do Sudoeste da Bahia, Departamento de Ciências Biológicas, Jequié, BA, Brazil. E-mail: juvenaljr@yahoo.com.br 
Palavras-chave: Inventário, Diversidade de vespas, Vespas sociais, Vespidae.

\section{INTRODUCTION}

Inventories of faunal species are an important step towards knowing the biodiversity of a region. Such studies are valuable and contribute information to wider studies on the ecological features of a habitat or ecosystem (MARQUES et al. 1993). The estimation of the number of insect species occurring in a biological community supports proposals of biodiversity conservation (STEWART et al. 2007).

The family Vespidae is monophyletic, widely distributed, and includes six subfamilies: Masarinae, Eumeninae, Polistinae, Euparagiinae, Stenogastrinae and Vespinae (CARPENTER 1981, 1993). From these, only the former three occur in Brazil, with Polistinae being particularly important owing to its high species diversity, as well as its observed behavioral and morphological variability, mainly in the Neotropical region (CARPENTER, 1991).

The world fauna of social wasps in the subfamily Polistinae is constituted by 26 genera and around 900 species. In Brazil, there are 21 genera and approximately 304 species, with 104 of them being endemic (CARPENTER, 2004). According to CARPENTER (1993), the Polistinae occurring in Brazil belong to three tribes: Polistini (Polistes), Mischocyttarini (Mischocyttarus) and Epiponini (remaining genera). The Epiponini constitute the most diverse tribe, corresponding to 19 genera (CARPENTER, 2004).

RICHARDS (1978) recorded the occurrence of 48 species of social wasps in the state of Bahia, although he did not inform the localities where collections were carried out. Recent inventories in different biomes raised the number of described species to 64. In the Atlantic Forest, it is worth mentioning the works of MARQUES et al. (1991), with six new species, and MENEZES (2009) and MENEZES et al. (2010), each with a new recorded species. In the Caatinga (i.e. Brazilian semi-arid biome), it is worth noting the contribution by SANTOS et al. (2009a), with a new catalogued species. In the Cerrado (i.e. Brazilian savannah), SANTOS et al. (2009b) found four new records, and in mangrove, Atlantic Forest and Restinga (i.e. Brazilian coastal vegetation), the work by SANTOS et al. (2007) reported three new records.

However, there is a gap in the knowledge on the diversity of these wasps in the central-south region of Bahia, particularly in the zones of transition between Caatinga and Atlantic Forest, whose phytophysiognomies and climate conditions are distinct from those of the areas already studied. Areas of transition or ecotones feature an environment where different ecological communities meet (KARK and VAN-RENSBURG, 2006). Often, such regions feature high species richness and a variety of ecological niches, possibly including organisms of adjacent communities (ODUM and BARRETT, 2008). CARDOSO and QUEIROZ (2011) note that, although the Caatinga is among the most threatened decidual vegetation types in the 
Neotropical Region, being affected by extensive destruction of natural areas, it is also underappreciated regarding biodiversity studies and has been supported by few conservationist endeavors, with the smallest protected area among all Brazilian biomes (LEAL et al. 2005). Recent studies have shown the Caatinga to be a region of high biodiversity and of great interest to studies of distribution in phylogenetic patterns (CARDOSO and QUEIROZ, 2011).

Thus, the current work aimed at carrying out an inventory of social wasp species (Vespidae: Polistinae) in fragments of Caatinga and Atlantic Forest in the central-south region of the state of Bahia.

\section{METODOLOGY}

The collections of social wasp nests were carried out between March 2010 and June 2011 in rural localities of the central-south region of the state of Bahia, namely in the municipalities of Brejões ( $\left.\mathrm{S}_{13}{ }^{\circ} 04^{\prime} 18.6^{\prime \prime} ; \mathrm{W}_{39}^{\circ} 47^{\prime} 02.2^{\prime \prime}\right)$, Jequié ( $\mathrm{S}_{13}^{\circ} 52^{\prime} 03.7^{\prime \prime}$;

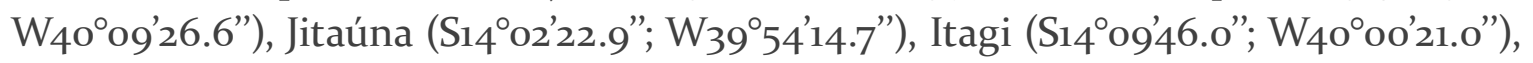
Ibirataia (S14 09'46.0"; W40 oo'21.o"), Poções (S14 3148.0"; W40 21'54.0") and Dário Meira (S14 26 '09.0"; W39 $\left.{ }^{\circ} 4^{\prime} 28.0^{\prime \prime}\right)$, all in the surroundings or within areas between Caatinga and Atlantic forest (Fig. 1).

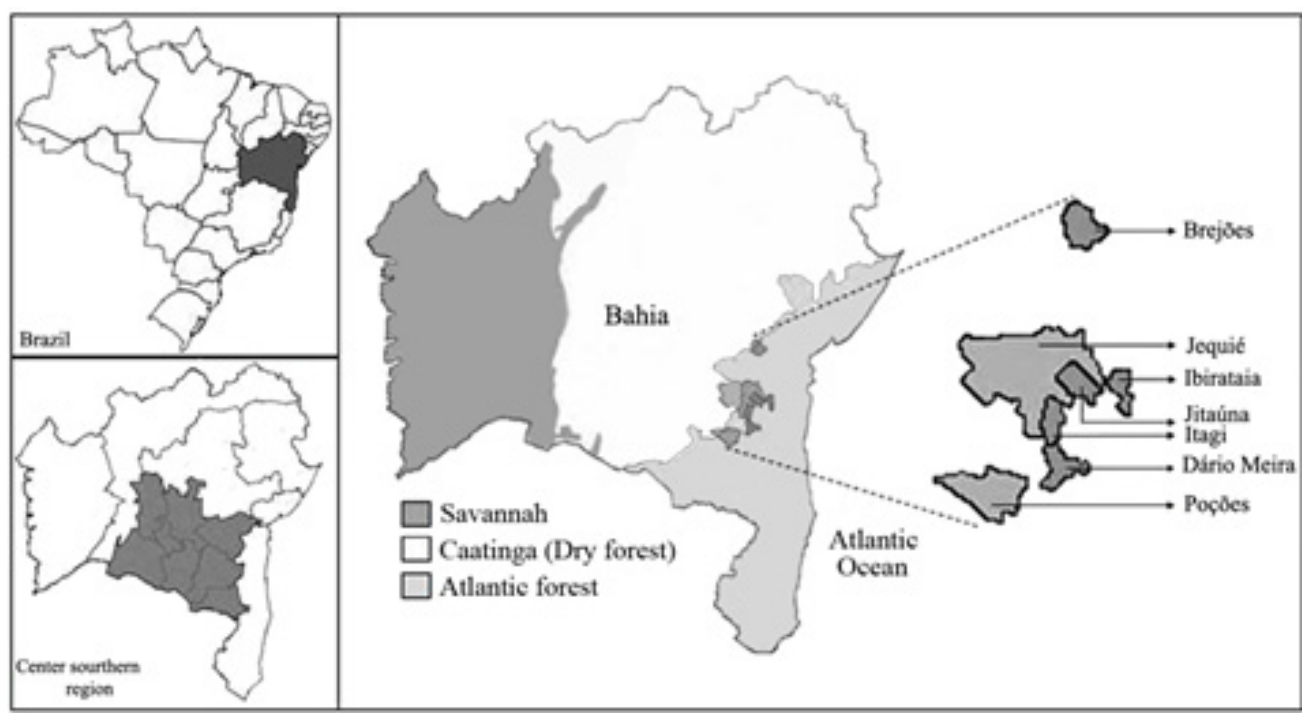

Fig. o1: Location of the sampling municipalities in the central-south region of Bahia Brazil.

In the municipalities of Brejões, Jequié and Poções, sampling was carried out in areas where the phytophysiognomy is typical of the dry, decidual forests of Caatinga, with a typically branched, spiny shrub vegetation, plenty of bromeliads, spurges, 
cacti and leguminosae, surrounded by areas with highly irregular and discontinuous rainfall (LEAL et al. 2005).

In the municipalities of Itagi, Jitaúna, Ibirataia and Dário Meira, there are remnants of montane, semideciduous seasonal forest, which are more closely related to the Atlantic Forest. Many of its species are quoted as being endemic of southern Bahia and northern Espirito Santo, and a few from the Caatinga (MACEDO, 2007 unpublished data).

The climate of the region is variable. In the transition between the dry forest (Caatinga) and the wet forest (Atlantic Forest), climate varies from sub humid to dry and semiarid, with annual mean temperature of $22.07^{\circ} \mathrm{C}$ and mean annual rainfall of 679.03mm (BAHIA, 2010, 2011a and 2011b). However, in the fragments of semideciduous seasonal Forest, climate varies from humid to sub humid and dry, with a mean annual temperature of $24.00^{\circ} \mathrm{C}$ and a mean annual rainfall of $1207.18 \mathrm{~mm}$ (BAHIA, 2011b) Table 1.

Table o1: Climate data from the sampled areas belonging to municipalities in the centralsouth region of the state of Bahia.

\begin{tabular}{lccc}
\hline MUNICIPALITY & Climate type & $\begin{array}{c}\text { Mean annual } \\
\text { temperature }\left({ }^{\circ} \mathbf{C}\right)\end{array}$ & Annual rainfall (mm) \\
\hline Brejões & Sub humid to dry & 21.2 & 936.6 \\
Jequié & Semi-arid & 24.3 & 617.5 \\
Poções & Semi-arid & 20.7 & 483 \\
Mean & - & $\mathbf{2 2 . 0 7}$ & $\mathbf{6 7 9 . 0 3}$ \\
\hline Jitaúna & Humid to subhumid & 24.5 & 1315.6 \\
Itagi & Humid to subhumid & 24.5 & 1315.6 \\
Ibirataia & Sub humid to dry & 23.8 & 1088.1 \\
Dário Meira & Sub humid to dry & 23.2 & 1109.4 \\
Mean & - & $\mathbf{2 4 . 0 0}$ & $\mathbf{1 2 0 7 . 1 8}$ \\
\hline
\end{tabular}

We used active search of nests as sampling method, which consisted in looking for them in existing trails in the sampling areas. We focused on buildings, branches, trunks and leavesin the vegetation. Once a nest was found, it was collected, put into a plastic bag and transported to the Laboratory of Insect Biology (Laboratório de Biologia de Insetos) at the Jequié (BA) campus of Universidade Estadual do Sudoeste da Bahia, Adults were mounted in entomological needles or kept in individual tubes with ethanol in a freezer at $-20^{\circ} \mathrm{C}$. Insect identification was carried out under a stereomicroscope, with the aid of dichotomous keys by RICHARDS (1978), CARPENTER (2004), PICKETT and WENZEL (2007), SILVEIRA (2008) and ANDENA et al. (2009). The collected specimens were deposited in reference collections in Laboratory of Insect Biology (UESB) and in the Laboratory of Ecology 
and Systematics of Pollinators (Laboratório de Ecologia e Sistemática de Polinizadores) at the Universidade Federal do Maranhão, São Luis/MA.

\section{RESULTS}

From the 90 collected nests, 22 species were identified, as well as three subspecies and one morphospecies of social wasps belonging to ten genera and eight subgenera. In the areas of dry, caducifolious forest, we identified 13 species and two subspecies, which represented $5 \mathbf{2 . 1 7} \%$ of the collected nests. In the areas of semideciduous, seasonal forests, in the domain of Atlantic Forest, we identified 14 species, two subspecies and one morphospecies, which represented $47.73 \%$ of the collected nests (Table 2).

Table o2: List of species, percentage of sampled nests and sampling locations of social wasps collected in areas of transition between Caatinga and Atlantic Forest.

\begin{tabular}{|c|c|c|}
\hline Ecosystem / Tribe / Species & Percent & Collection Sites \\
\hline \multicolumn{3}{|l|}{ DRY AND DECIDUOUS FOREST (CAATINGA) } \\
\hline \multicolumn{3}{|l|}{ Epiponini } \\
\hline Apoica (Apoica) flavissima (Van der Vecht, 1973) & 4.44 & Brejões and Jequié / BA \\
\hline Brachygastra lecheguana (Latreille, 1824) & 3.33 & Brejões / BA \\
\hline Polybia (Formicicola) rejecta (Fabricius, 1798) & 1.11 & Jequié / BA \\
\hline Polybia (Myrapetra) occidentalis sp1 & 5.55 & Brejões and Jequié / BA \\
\hline Polybia (Myrapetra) occidentalis sp2 & 1.11 & Poções / BA \\
\hline Polybia (Myrapetra) ruficeps xanthops (Richards, 1978) & 3.33 & Brejões / BA \\
\hline Polybia (Trichothorax) chrysothorax (Lichtenstein, 1796) & 2.22 & Brejões / BA \\
\hline Polybia (Trichothorax) ignobilis (Haliday, 1836) & 1.11 & Brejões / BA \\
\hline Polybia (Trichothorax) sericea (Olivier, 1791) & 4.44 & Brejões and Jequié / BA \\
\hline Protopolybia exigua (de Saussure, 1854 ) & 6.66 & Jequié / BA \\
\hline Total Epiponini & 33.30 & \\
\hline \multicolumn{3}{|l|}{ Polistini } \\
\hline Polistes (Aphanilopterus) versicolor (Olivier, 1791) & 9.99 & Jequié / BA \\
\hline $\begin{array}{l}\text { Polistes (Aphanilopterus) canadensis borientalis (Richards, } \\
\text { 1978) }\end{array}$ & 3.33 & Jequié / BA \\
\hline Total Polistini & 13.32 & \\
\hline \multicolumn{3}{|l|}{ Mischocyttarini } \\
\hline Mischocyttarus (Monocyttarus) cearensis (Ricards, 1945) & 1.11 & Jequié / BA \\
\hline $\begin{array}{l}\text { Mischocyttarus (Mischocyttarus) rotundicolis (Cameron, } \\
\text { 1912) }\end{array}$ & 2.22 & Jequié / BA \\
\hline Mischocyttarus sp1 & 2.22 & Jequié / BA \\
\hline Total Mischocyttarini & 5.55 & \\
\hline Partial - Biome Caatinga & 52.17 & \\
\hline
\end{tabular}




\begin{tabular}{|c|c|c|}
\hline Ecosystem / Tribe / Species & Percent & Collection Sites \\
\hline \multicolumn{3}{|l|}{ Epiponini } \\
\hline Angiopolybia pallens (Lepeletier, 1836) & 1.11 & Itagi / BA \\
\hline Metapolybia decorata (Gribodo, 1896) & 5.55 & Dário Meira / BA \\
\hline Parachartergus fraternus (Gribodo, 1891) & 1.11 & Ibirataia / BA \\
\hline Polybia (Apopolybia) jurinei (Saussure, 1854) & 2.22 & Itagi and Jitaúna / BA \\
\hline Polybia (Formicicola) rejecta (Fabricius, 1798) & 1.11 & Ibirataia / BA \\
\hline Polybia (Myrapetra) catillifex (Moebius, 1856) & 3.33 & Itagi and Ibirataia / BA \\
\hline Polybia (Myrapetra) sp. 4 & 1.11 & Dário Meira / BA \\
\hline Polybia (Myrapetra) occidentalis sp.1 & 1.11 & Jitaúna / BA \\
\hline Polybia (Myrapetra) occidentalis sp.2 & 1.11 & Ibirataia / BA \\
\hline Polybia (Myrapetra) platycephala (Richards, 1978) & 2.22 & Itagi / BA \\
\hline Polybia (Trichothorax) chrysothorax (Lichtenstein, 1796) & $7 \cdot 77$ & Itagi and Ibirataia / BA \\
\hline Polybia (Trichothorax) sericea (Olivier, 1791) & 2.22 & Jitaúna and Dário Meira / BA \\
\hline Protopolybia (de Saussure, 1854) & 1.11 & Ibirataia / BA \\
\hline Synoeca cyanea (Fabricius, 1775) & 2.22 & Itagi and Ibirataia / BA \\
\hline Total Epiponini & 33.30 & \\
\hline \multicolumn{3}{|l|}{ Polistini } \\
\hline Polistes (Aphanilopterus) versicolor (Olivier, 1791) & 4.44 & Jitaúna and Dário Meira / BA \\
\hline Total Polistini & $4 \cdot 44$ & \\
\hline \multicolumn{3}{|l|}{ Mischocyttarini } \\
\hline Mischocyttarus (Monocyttarus) cassununga (R. von Ihering, 1903) & 9.99 & Dário Meira / BA \\
\hline Total Mischocyttarini & 9.99 & \\
\hline Partial - Atlantic forest Biome & 47.73 & \\
\hline GRAND TOTAL & 100 & \\
\hline
\end{tabular}

We found that only six taxa were common to both studied ecosystems: Polybia (Formicicola) rejecta, Polybia (Myrapetra) occidentalis sp.1, Polybia (Myrapetra) occidentalis sp.2, Polybia (Trichothorax) chrysothorax, Polybia (Trichothorax) sericea and Polistes (Aphanilopterus) versicolor. In parallel, nine species were sampled only in the areas of dry forest and eleven others were solely sampled in areas of semideciduous seasonal forest.

Nests of wasps in the genus Polybia (Lepeletier) were the most frequent (41.07\%), with $18.87 \%$ belonging to the subgenus Myrapetra, $17.76 \%$ to the subgenus Trichothorax, and $4.44 \%$ belonging to the subgenera Apopolybia and Formicicola. Polybia was also the most diverse genus, with eight identified species, three subspecies in the occidentalis group and one morphospecies, for a total of 12 taxa.

In this study, the species Polybia (Myrapetra) occidentalis was sampled in five of the eight investigated municipalities and had three subspecies, here treated as sp1, sp2 and sp3. Species in the genera Polistes and Mischocyttarus accounted together for $33.3 \%$ of the collected nests. 


\section{DISCUSSION}

The six taxa sampled in the studied ecosystems display a higher efficiency in the use of the contrasting ecological conditions of vegetation, temperature and resource availability in the two phytophysiognomies. The sampling of these species was expected, as the genera Polybia and Polistes have broad geographic distribution. The taxa sampled only in the areas of dry forest or in areas of wet forest may be more adapted to the environmental specificities of each phytophysiognomy.

Five species identified in this work constitute the first records of occurrence for the state of Bahia: Apoica (Apoica) flavissima and Mischocyttarus (Monocyttarus) cearensis, sampled in the Caatinga, as well as Parachartergus fraternus, Polybia (Myrapetra) catillifex and Polybia (Myrapetra) platycephala, sampled in the domain of Atlantic Forest. Literature data, together with the new records of occurrence mentioned in the present work, point to the current existence of around 70 species of Polistinae recorded for the state of Bahia.

The high diversity of the genus Polybia was already expected, considering that, from the 58 valid species distributed from southern United States to northern Argentina, 44 species have already been recorded in Brazil, 16 of them in the state of Bahia (RICHARDS 1978; MARQUES et al. 1993; SANTOS et al. 2007).

The three subspecies and the morphospecies in the genus Polybia that were not completely identified, belong to the subgenus Myrapetra, the largest among the Polybia genera. Myrapetra is treated as a subgenus of problematic classification, owing to the variety of colors found in its specimens and the apparent confusion of its morphological patterns. This is particularly true for those species and subspecies in the $P$. occidentalis group, which are differentiated by the yellow coloration of different parts of the body (RICHARDS, 1978), which constitutes a taxonomic character with little robustness.

Four species identified in this study have not been reported in recent inventories carried out in different phytophysiognomies in the state of Bahia: Mischocyttarus (Mischocyttarus) rotundicolis and Polybia (Myrapetra) ruficeps xanthops, which were sampled in the Caatinga, as well as Polybia (Apopolybia) jurinei and Protopolybia sedula, collected in the Atlantic Forest. These species have not been reported from studies in the state of Bahia since RICHARDS (1978).

The high frequency of nests of the genera Polistes and Mischocyttarus may be due to the fact that these wasps display the behavior of founding a primary nest followed by new, smaller nests around the original one (satellite nests) in due time, which are probably founded by daughters of the females that founded the original nest (RICHARDS, 1978; CARPENTER, 1991; NASCIMENTO, et al. 2008).The construction of satellite nests reinforces territorial behavior in many species of social wasps in which the distance between recently founded colonies and the mother one is short (JEANNE, 1980). 
The species Protopolybia exigua (6.66\%), Brachygastra lecheguana (3.33\%) and Synoeca cyanae $(2,22 \%)$ have already been recorded in the state of Bahia in inventories carried out by MARQUES et al. (1993), SANTOS et al. (2007) and SANTOS et al. (2009b). The species Angiopolybia pallens (1.11\%) has also been recorded in the works by SANTOS et al. (2007) and SANTOS et al. (2009a). The species Metapolybia decorata (5.55\%) has been recorded in the Atlantic Forest of southern Bahia by MENEZES et al. (2013). Polybia (Myrapetra) sp. 1 (1.11\%) is probably an undescribed species.

The data obtained in this work corroborate the diversity of described species in different phytophysiognomies in the state of Bahia, as exemplified by the works of MARQUES et al. (1993), who identified 20 species in the domain of Atlantic Forest; SANTOS et al. (2007), who found 21 species in areas of mangrove, Atlantic Forest and Restinga; SANTOS et al. (2009a), who found 17 specie in Caatinga; and SANTOS et al. (2009b), who found 19 in Cerrado.

These results point to a rich fauna of Polistinae in the studied region, especially regarding species in the genus Polybia, as these were the most abundant. These areas, by offering a greater variety of ecological niches, can attract species of social wasps from adjacent ecosystems and, perhaps, the insect fauna as whole. However, this will only be known by studies using other sampling methods that better characterize the faunal composition of the sampled areas.

Insect conservation has been hampered by a set of preconceived and essentially pejorative ideas about these organisms, which are reinforced by the paucity of ethnobiological studies and educational, conscientization activities (COSTA-NETO, 200o). In the particular case of social wasps, most are repelled by many people who are culturally inclined to eliminate them, often by burning their nests. Such aversion is related to the direct association of these animals to their painful sting (COSTANETO, 2004).

Nevertheless, it is worth noticing that the scientific community has given greater attention to the need for insect diversity conservation in recent years, by recognizing that many species are being extinct at a fast pace and by underscoring the important role that insects play in the maintenance of ecological processes (SAMWAYS, 2005). It is known that social wasps play the relevant role of generalist predators of larvae and other insect orders in the environment (JEANNE and TAYLOR, 2009), as well as effective pollination agents (CARPENTER, 1991). Thus, investigations that result in a more representative list of social insects, as well as studies on their biology, including threatened species, should be a priority as these can contribute to the elaboration of a basis for effective conservation strategies (CHAPMAN and BOURKE, 2001). 


\section{ACKNOWLEDGEMENTS}

We are grateful to researcher Luiz F. F. Gelin (UNESP) forhis support in identifying species in the genus Polybia, and to Dr. Orlando T. Silveira (MPEG) and Msc. José Nazareno dos S. Júnior (UFPA) for their support in identifying the remaining specimens of Polistinae to CAPES for the financial support.

\section{REFERENCES}

ANDENA, S. R.; CARPENTER, J. M.; and NOLL, F. B. 2009 - A phylogenetic analysis of Synoeca de Saussure, 1852 , a neotropical gens of social wasps (Hymenoptera: Vespidae: Epiponini). Entomologica Americana 115: 81-89.

BAHIA, Superintendência de Estudos Econômicos e Sociais da Bahia - Estatística dos municípios baianos. Salvador: SEI, 2010. V. 4. Disponível em: http://www.sei.ba.gov. br/index.php?option=com_content\&view=article\&id=76\&Itemid=110. Acesso em: o6/01/2013.

BAHIA, Superintendência de Estudos Econômicos e Sociais da Bahia - Estatística dos municípios baianos. Salvador: SEI, 2011a. v. 17. Disponível em: http://www.sei.ba.gov. br/index.php?option=com_content\&view $=$ article\&id $=76 \&$ Itemid $=110$. Acesso em: o6/01/2013.

BAHIA, Superintendência de Estudos Econômicos e Sociais da Bahia - Estatística dos municípios baianos. Salvador: SEI, 2011b. v. 18. Disponível em: http://www.sei.ba.gov. br/index.php?option=com_content\&view $=$ article\&id $=76 \&$ Itemid $=110$. Acesso em: o6/01/2013.

CARDOSO, D. B. O. S. and QUEIROZ, L. P. 2011 - Caatinga no contexto de uma metacomunidade: evidências da biogeografia, padrões filogenéticos e abundância de espécies em Leguminosas; pp 241-26o. In: CARVALHO, C. J. B. and ALMEIDA, E. A. B. (Eds.), Biogeografia da América do Sul: padrões e processos. Roca, São Paulo.

CARPENTER, J. M. 1981 - The phylogenetic relationships and natural classification of the Vespoidea (Hymenoptera). Systematic Entomology 7: 11-38.

CARPENTER, J. M. 1991 - Phylogenetic relationships and the origin of social behavior in the Vespidae; pp 7-32. In: ROSS, K. G. and MATTHEWS, R. W. (Eds.), The Social Biology of Wasps. Cornell University, Ithaca. 
CARPENTER, J. M. 1993 - Biogeographic patterns in the Vespidae (Hymenoptera): Two views of Africa and South America; pp 139-155. In: GOLDBLATT P. (Ed.), Biological relationships between Africa and South America. Yale University Press, New Haven.

CARPENTER, J. M. 2004 - Synonymy of the genus Marimbonda Richards 1978, with Leipomeles Möbius 1856 (Hymenoptera: Vespidae; Polistinae), and a new key to the genera of paper wasps of the New World. American Museum Novitates 3.465: 1-16.

CHAPMAN, R. E. and BOURKE, F. G. 2001 - The influence of sociality on the conservation biology of social insects. Ecology Letters 4: 650-662.

COSTA-NETO, E. M. 2000 - Introdução à etnoentomologia: considerações metodológicas e estudo de casos. Editora-UEFS, Feira de Santana. 131 p.

COSTA-NETO, E. M. 2004 - La etnoentomología de las avispas (Hymenoptera, Vespoidea) en el poblado de Pedra Branca, estado de Bahia, nordeste de Brasil. Boletín de la SEA 34: 247-262.

JEANNE, R. L. 1980 - Evolution of social behavior in the Vespidae. Annual Review Entomology 25: 371-396.

JEANNE, R. L. and TAYLOR, B. J. 2009 - Individual and social foraging in social wasps; pp 53-79. In: JARAU, S. and HRNCIR, M. (Eds.), Food Exploitation by Social Insects: Ecological, Behavioral, and Theoretical Approaches. USA: CRC Press, Boca Raton. 360 p.

KARK, S. and VAN-RENSBURG, B. J. 2006 - Ecotones: Marginal or central areas of transition? Israel Journal of Ecology and Evolution 52: 29-53.

LEAL, I. R.; SILVA, J. M.; TABARELLI, M.; and LACHER-JR, T. E. 2005 - Mudando o curso da conservação da biodiversidade na Caatinga do Nordeste do Brasil. Megadiversidade 1: 139-146.

MARQUES, O. M.; CARVALHO, C. A. L.; and COSTA, J. M. 1993 - Levantamento das espécies de vespas sociais (Hymenoptera, Vespidae) no Município de Cruz das Almas - Estado da Bahia. Insecta, 2: 1-9.

MENEZES, R. S. T.; CARVALHO-FILHO, A. F.; RAW, A. and COSTA, M. A. 2010 Epipona media Cooper (Hymenoptera: Vespidae), a Social Wasp New to the Brazilian Atlantic Forest. Neotropical Entomology 39: 1046-1047. 
MENEZES, R. S. T.; SILVA, T. M.; CARVALHO, A. F.; ANDRADE-SOUZA, V.; SILVA, COSTA, M. A. 2013 - Numerical and structural chromosome variation in the swarmfounding wasp Metapolybia decorata Gribodo 1896 (Hymenoptera, Vespidae). Genética, 141: 273-280.

NASCIMENTO, F. S.; TANNURE-NASCIMENTO, I. C.; and MATEUS, S. 2008 - Vespas sociais neotropicais: padrões comportamentais, regulação social e arquitetura de ninho; pp 47-67. In: SANTOS, I. A.; VILELA, E. F.; SCHOEREDER, J. H.; CAMPOS, L. A. O.; and SERRÃO, J. E. (Eds.), Insetos sociais: da biologia à aplicação. Editora UFV, Viçosa. vol. 1. 442 p.

ODUM, E. P. and BARRETT, G. W. 2008 - Fundamentos de Ecologia. Cengage Learning, São Paulo. 612 p.

PICKETT K. M. and WENZEL, J. W. 2007 - Revision and cladistics analysis of the nocturnal social wasp gens, Apoica Lepeletier (Hymenoptera: Vespidae; Polistinae, Epiponini). American Museum Novitates 3562: 1-30.

RAW, A. 1992 - The forest: savanna margin and habitat selection by Brazilian social wasps (Hymenoptera, Vespidae); pp 499-511. In: FURLEY, P. A.; RATTER, J. A.; and PROCTOR, J. (Eds.), The nature and Dynamics of the Forest-Savanna Boundary. Chapman and Hall. 644 p.

RICHARDS, O. W. 1978 - The social wasps of the Americas (excluding the Vespinae). British Museum (Natural History), London. 580 p.

RICHTER, M. R. 2000 - Social wasps (Hymenoptera, Vespidae) foraging behavior. Annual Review Entomology 45: 121-150.

SAMWAYS, M. J. 2005 - Insect Diversity Conservation. Cambridge University Press, New York. 342 p.

SANTOS, G. M. M.; BICHARA-FILHO, C. C.; RESENDE, J. J.; DA CRUZ, J. D.; and MARQUES, O. M. 2007 - Diversity and community structure of social wasps (Hymenoptera, Vespidae) in three ecosystems in Itaparica Island, Bahia State, Brazil. Neotropical Entomology 36: 180-185.

SANTOS, G. M. M.; BISPO, P. C.; and AGUIAR, C. M. L. 20o9a - Fluctuations in richness and abundance of social wasps during the dry and wet seasons in three phyto-physiognomies at the tropical dry forest of Brazil. Environmental Entomology 38: 1613-1617. 
SANTOS, G. M. M.; CRUZ, J. D.; MARQUES, O. M.; and GOBBI, N. 2009b - Diversidade de Vespas Sociais (Hymenoptera:Vespidae) em Áreas de Cerrado na Bahia. Neotropical Entomology 38: 317-320.

SILVEIRA, O. T. 2008 - Phylogeny of wasps of the genus Mischocyttarus de Saussure (Hymenoptera, Vespidae, Polistinae). Revista Brasileira de Entomologia 52: 510-549.

STEWART, A. J. A.; NEW, T. R.; and LEWIS, O. T. 2007 - Insect Conservation Biology. CABI Publishing, Wallingford. 457 p. 